\title{
Exploring the Factors on Micro and Small Women Entrepreneurs' Success in Northern Province of Sri Lanka
}

\author{
Rathiranee Yogendrarajah \\ Senior Lecturer, Department of Financial Management \\ University of Jaffna, Sri Lanka \\ E-mail: rathi@univ.jfn.ac.lk
}

Received: January 13, 2019

Accepted: February 8, 2019 Published: February 17, 2019

doi:10.5296/ijafr.v9i1.14221

URL: https://doi.org/10.5296/ijafr.v9i1.14221

\begin{abstract}
This study aims to identify the factors that contribute to the success of Micro and small women entrepreneurs in the Northern Province of Sri Lanka. Being 52\% of the total population in Sri Lanka, women are still being covered the population. With the consideration of the importance of women entrepreneurship, it is better to identify the factors contributing to the success of women entrepreneurs. A quantitative method was used for gathering information and stratified sampling method was used for collecting data from 284 women entrepreneurs engaged in several activities. In the process of collecting data, a questionnaire was designed to recognize the factors that influence the success of women entrepreneurs in Micro and small enterprises. Further, interviews and discussions also were held with selected entrepreneurs and officers from Divisional Secretariat Offices. After the data collection, the data analysis was made with the help of simple statistical techniques, descriptive statistics and reduction of variables (Factor analysis) by using SPSS package. The results of the study revealed that nine key variables out of thirty one contributes to the women entrepreneurs' success in Northern Province of Sri Lanka those are motivation, self-efficacy, network, risk taking, financial strength, locus of control, problem solving, leadership and environment. The finding of this study is helpful for the micro and small entrepreneurs as well as researchers regarding the area of women entrepreneurs to further study.
\end{abstract}

Keywords: Factor analysis, Influencing factors, Micro and small enterprises, Key variables and women entrepreneurs 


\section{Introduction}

A woman or group of women begin, organize and run a business enterprise is defined as a women entrepreneur. Owners of small businesses that have startup costs of less than $\$ 35,000$, less than five employees and less than $\$ 100,000$ of annual revenue are called as micro-entrepreneurs. Micro enterprises play an important role in economic output and employment opportunity in developing economies. Micro entrepreneurs face barriers in getting initial cost and lack of managerial skills that unable to manage the sustainability and growth of their business due to insufficient resources. As a result of this, micro-entrepreneurs can't improve and expand their business beyond a micro level organization. Although, they face challenges we can't neglect their success in their business activities. In Sri Lanka, in the post-war context women lost their male relatives and loved ones which forced them to take the family responsibility to look after their children and parents and they are the breadwinners. They have to initiate any micro-entrepreneurial activities or business as income generating activities. As a developing country, Sri Lanka was affected by the internal conflict over 30 years. In the post-war context, development is carried out in the northern province of the country, however, the war widows, disabled persons, and female children are suffering from accessing education, health nutrition, and employability.

Women-owned enterprises grow from time to time (Davidson \& Burke, 2004). McKay (2001) stated that half of the small businesses in US are possessed by women in 1999. Still and Timms (2000) reported that women contributed a key role in small businesses development in Australia. Further, it also assessed that a quarter of business enterprises were owned by women in UK (Fielden, Davidson, Dawe \& Makin, 2003). Orhan and Scott (2001) described that $26 \%$ of entrepreneurs in France are women. Mei Fun (2009) revealed that $16 \%$ of the small and medium enterprises on service, manufacturing, and agriculture sectors are engaged by women in Malaysia. With this fact it could be realized that there are numerous success stories regarding women entrepreneurs all over the world (Alam, Jani \& Omar, 2011). Successful micro and small women enterprises contribute to the society and country as well. So, it could be identified that various factors encourage women to initiate business venture and developing their business activity on their own. Nevertheless, most of the available studies on this regards in Sri Lanka are on male entrepreneurs with restricted exposure to females. Thus, this study attempt to identify what factors contributing to the success of women entrepreneurship in Northern Part of Sri Lanka.

Small and Medium-women entrepreneurs represent only $30 \%$ to $37 \%$ of all SMEs (8m to $10 \mathrm{~m}$ ) businesses) in developing markets. This is the biggest barrier identified by Musa (2015) to the growth and development. Though female entrepreneurs have now stimulated from microenterprise businesses to Small and Medium Enterprises (SMEs), the numbers withstand remarkably small. Though 80 percent of the economy is determined by the SMEs only 10 percent involves of women entrepreneurs in Sri Lanka (Business Times, 2017). Further, it was noted that 52 percent of the population is women. If 52 percent is not generating sufficient income any country can't expect to improve economically. It has also ensued in the lack of research regarding their success stories. A huge amount of researches have been done on development of entrepreneurship in a diverse setting (Rahman et al., 1979; Saleh, 1995; 
Aktaruddin, 1999). However, the most of the available studies on entrepreneurs in Sri Lanka are on male entrepreneurs (Farook, 1992; Fernando, 2006; Gunatillake,1992; Karunanayake \& Senadheera, 2006; Kodithuwakku, 1992; Perera \& Buddhadasa, 1992; Ranasinghe, 1996). But a few kinds of research focused on women entrepreneurs (Rotaru, 2009; Afrin et al., 2008; Hossienie, 2011; Rahman \& Hossain, 1999). Therefore this study tried to identify the factors that contribute to the success of women entrepreneurs. Therefore, from this problem statement, the following research questions have been arisen.

1. What are the factors influences on Micro women entrepreneurs' success?

2. Whether these factors have an impact on their venture success if so at what extent it has an impact on entrepreneurs' success?

In line with these issues above, the main objective of this study is:

i. To identify the factors behind the success of Micro women entrepreneurs in Northern Part of Sri Lanka.

The following sub-objectives are derived from the main objective.

ii. To assess how these factors relate to women entrepreneurs' success.

iii. To investigate the impact of these factors on women entrepreneurs' success.

The main objective of the study was achieved through the factor analysis. The factors that contribute to the success were explored and the reduction was then made. These variables were used to achieve the sub-objectives of the study.

\section{Theoretical Background and Hypothesis Development}

Several studies intensive on women entrepreneurs' success factors (Brown, 1997; Chandralekha et al, 1995; Gundry et al., 2002; Helmi's, 1997; Hamilton, 1993; Stoner et al, 1990; Winn, 2005). Naser et al., (2009) recognized success factors of women entrepreneurs which were Self-fulfillment, knowledge, skills, experience, and relationship to spouse/father business. According to White and Cooper (1997), a higher level of education leads to successful ventures. Further, successful women entrepreneurs have family support (Schlosser 2001; Winn 2004), family support and social networking (Kodithuwakku \& Perera, 2003), government support (Sandberg, 2003) and business background of their relatives rather than education (Amarasiri, 2002).

According to Marlin \& Wright (2005), internal motivation is an important factor that can contribute to the success of the venture. Further, innovation through Information Communications Technology (ICT) shows a significant role in assisting women entrepreneurs to get success. Social support is another key factor to lead their business successfully. Alam et al., (2011), acknowledged that the family support; social network and internal motivation influence positively and significantly to the success. Further, social recognition, consumer satisfaction, diversification, personal freedom, and security are the success factors (Akhalwaya \& Havenga, 2012). According to Seuwandhi and Ranasinghe, childhood experiences, psychological characteristics, entrepreneurial competencies, formal 
and informal learning and external support and culture contribute to success which was captured through qualitative research method in Sri Lanka.

Sandip Sarker (2015) identified 8 factors among 25 factors as significant for their success by conducting factor analysis. Those were access to technology, interpersonal skill, business feature, training and motivation, social security and freedom, assistance and easy regulation, family support and quality assurance and risk encountering. Further, this study exposed that there is no significant relationship between the age differences of women entrepreneur and the success factors. And they suggested this study can be used for further analysis of how much significant those factors are for women entrepreneur success.

Perren (1999) and Amit, Mac Crimmon, Zietsma and Oesch (2000) concluded that the measurement of business success is income, growth, wealth and profit and the ability of the business to remain longer in the industry. Watson, orgarth-Scott and Wilson (1998) and Dafna (2008) appraised that business success through its ability to constantly carry out its business activities. Ashraf and Qureshi (2010) measured entrepreneurial success based on the company's financial strength, customer satisfaction and entrepreneurs' satisfaction.

Individual characteristics, parental influence, business motivation and goals, business strategies, goals and motives, networking and entrepreneurial orientation were the contributing factors of successful performance of the women entrepreneurs (Theo et al., 2007). Enock (2010) revealed that access to finance, access to business information, access to infrastructure, government policy and regulations and management experience are the factors influencing business performance. Cooper et al (1994) investigated the several factors that experience, education, occupation of parents, gender, race, age, and entrepreneurial goals which influence business performance. Fridah, (2012), and Mahbub, (2000) disclosed training, economic, social and education are important factors in contributing to the performance of these activities. Further, Samiti (2006) and Tan (2000) found the factors that contribute to the success of entrepreneurial activity are training, economic and social. In addition to this, Walelign and Wondimu (2002), and Eshetu \& Zeleke, (2008) revealed economic, education and training are influencing factors on entrepreneurial success. Karimi (2005) revealed that social and economic are the success factors of entrepreneurship. Thibault et al. (2002) suggested that factors influencing business performance are personal factors and business factors those are important factors in investigating the performance of small scale businesses. Learner and Hisrich (1997) examined that motivations and goals, social learning theory, network affiliation, human capital and environmental influences that affect the performance of women entrepreneurs in Israeli.

From the above literature, it is assumed that several factors have a relationship with the success of women entrepreneurs and the following hypotheses have been developed to achieve the objective of the study.

$\mathrm{H}_{1}$. There are various determinant factors that influence on women entrepreneurs' success.

$\mathrm{H}_{2}$. There is a relationship between identified factors and success of women entrepreneurs.

$\mathrm{H}_{3}$. The identified factors have a significant impact on women entrepreneurs' success. 
Women initiate self-employable jobs and develop entrepreneurship since opportunities for getting employment in either government/non-government or private organization (Gemechis, 2007).

\section{Research Method}

The population of this study was around 3,000 women entrepreneurs in the Northern Part of Sri Lanka as at December 2016 who has more than 3 years' experience on their ventures and less than 5 employees with the capital of less than $\$ 50,000$ and the sample of this study was drawn from this population. In addition to this, Purposeful sampling method was employed to conduct the focus group discussions and in-depth interviews, which were the methods used for qualitative analysis. Although the result of the research was highly dependent on the primary sources that researcher gathered information from secondary sources to understand the concepts, definitions, theories and empirical results. Researcher used books, research literatures, articles, reports, journals and thesis, as secondary sources for the study.

A stratified random sampling technique was adopted for selecting the sample size. The purpose for selecting this sampling technique is that in Sri Lanka, there are nine provinces of which Northern Province is the war affected area had only been selected. The respondents of the study were stratified randomly selected to be entirely women. The Northern Province includes 36 Divisional Secretariats Divisions (DS Divisions) and 861 Grama sevaka Divisions (GS Divisions) under five districts. Finally, the women entrepreneurs were selected who have been experienced more than 3 years to select nothing less than 40 numbers to make up the sample from each districts. It was difficult to identify potential women entrepreneurs who have been experienced more than 3 years because there were insufficient records on registration about their activities because most of them did not register their activity due to lack of awareness on registration and cost burden. Further, the registered entrepreneurs also were inactive in their business. However, the record was obtained from the Northern Province Industrial Department and selected only the female entrepreneurs in each five district. There were 1,419 active self-employable women in 2016 in Northern Province. In this situation after selecting some of the respondents, then the snowball sampling method also were used to identify the potential women entrepreneurs in those divisions. And finally, the women entrepreneurs were selected who had experience more than 3 years by using snow ball sampling method that make up the sample size of the research. The following table illustrates the sample population in the present study.

Table 1. Sample population of the study

\begin{tabular}{llllll}
\hline Districts & $\begin{array}{l}\text { Total Women } \\
\text { Entrepreneurs }\end{array}$ & $\begin{array}{l}\text { Sample } \\
\text { size of the } \\
\text { population }\end{array}$ & $\begin{array}{l}\% \text { of } \\
\text { sample } \\
\text { size }\end{array}$ & $\begin{array}{l}\text { selected respondents } \\
\text { from the sample size }\end{array}$ & $\begin{array}{l}\% \\
\text { respondents }\end{array}$ \\
\hline Jaffna & 510 & 110 & $22 \%$ & 102 & $35 \%$ \\
\hline Kilinochhi & 177 & 30 & $17 \%$ & 33 & $12 \%$ \\
\hline
\end{tabular}




\begin{tabular}{lccccc} 
Mannar & 225 & 50 & $22 \%$ & 45 & $16 \%$ \\
\hline Mullaitivu & 257 & 60 & $23 \%$ & 54 & $19 \%$ \\
\hline Vavuniya & 250 & 50 & $20 \%$ & 50 & $18 \%$ \\
\hline rejected & & & 16 & $21 \%$ \\
\hline Total & 1419 & 300 & $21 \%$ & 300 & \\
\hline
\end{tabular}

Source: Industrial Department - Northern Province - 2012.

According to the records of Industrial Department - Northern Province, the women who are involving in self-employment in Jaffna, Kilinochchi, Mannar, Mullaitivu and Vavuniya Districts around 510, 177, 225, 257 and 250 persons respectively. However, as per the above table, the selection of sample population is 110, 30, 50, 60 and 50 in Jaffna, Kilinochchi, Mannar, Mullaitivu and Vavuniya districts and altogether 300 women entrepreneurs were selected for the data collection purpose. However 300 was the sample, only 284 were the fully completed questionnaires and used for the study. Thereafter the 16 questionnaires were rejected which were not completed as per the requirement.

For the primary data collection, a structured questionnaire was developed based on the previous literature to collect the information. The questionnaire encompassed of background questions regarding gender, age, education and living standards, and questions related to income, saving, capital etc. The structured questionnaire had multiple-choice questions and the 'Likert Scale' considered on 1-5 point's scale was used to measure the respondents' perceptions based on their perceived success factors of their entrepreneurship activity. In this case, ' 1 ' denotes the lowest level of satisfaction or high disagreement, whereas ' 5 ' denotes the highest level of satisfaction or high agreement about the statements.

For Qualitative Analysis, Focus Group Discussions were organized to bring out the findings in compliance with the Quantitative Analysis. Six Focus Group Discussions (FGDs) which were consisting of women entrepreneurs from different areas of the Northern part of the country. Four FGDs each from Kilinochchi, Mannar, Vavuniya and Mullaitivu Districts and two from Jaffna District of Northern Province of Sri Lanka among the group members of 6 to 12 persons were conducted. The discussions were moderated by the researcher. The participants were selected and discussion was arranged by the field officers and WRDSs. The discussions conducted from half an hour to one hour and the information obtained was commonly very valuable. The ideas and opinions raised, the discussion held and the cooperativeness of the group members were also very much noticeable. Even though some members appear to be shy and a few try to dominate the discussions, the facilitator has mainly managed to switch the sessions well.

In addition to the focus group discussion, the in-depth interview was held according to the above to get more information from the respondents. The questions raised by the interview 


\section{MIMacrothink}

International Journal of Accounting and Financial Reporting

ISSN 2162-3082

2019, Vol. 9, No. 1

deal with entrepreneurs' personal background and business success. The privacy and confidentiality of the respondents were kept both through the interview and in the compiled reports. Most of the interviews conducted had been recorded while those made with some respondents had to be handwritten as the respondents opposed recording. The potential informants were advised of the schedules of the interview in advance by the staff of the departments. The researcher explained the objective of the research work to the respondents prior to the interview. The interviews generally conducted from 15 minutes to 30 minutes. The Audio and Video had been recorded to analyze and for getting results.

The descriptive and inferential analysis, accounting and mathematical techniques were mostly used in the study as the mode of analysis. With regards to the quantitative analysis, the SPSS software 21 version was employed for the data entry and to calculate percentage values. The resulting data was then analyzed and interpreted. In addition to this qualitative study also made to confirm the results of the quantitative study.

Factor analysis, correlation, regression analyses were used for inferential analysis it was needed to achieve the objectives of the study. Factor analysis assisted for reducing a large number of variables to a smaller number of assumed underlying hypothetical entities called factors. It tried to simplify complex and diverse relationships that exist among a set of observed variables by uncovering common dimensions of factors.

\section{Finding and Discussion}

Table 2. Personal or Demographic profiles of respondents

\begin{tabular}{|c|c|c|c|c|c|}
\hline Age & Frequency & Percent & $\begin{array}{l}\text { Size of the } \\
\text { Organization }\end{array}$ & Frequency & Percent \\
\hline Under 25 years & 30 & 10.6 & Micro & 206 & 72.5 \\
\hline 25-34 years & 122 & 43.0 & Small & 66 & 23.2 \\
\hline $35-44$ years & 76 & 26.8 & Medium & 12 & 4.2 \\
\hline 45-54 years & 48 & 16.9 & Total & 284 & 100.0 \\
\hline $55+$ years & 8 & 2.8 & Experience & & \\
\hline Total & 284 & 100.0 & 3 - 5 years & 105 & 37.0 \\
\hline Education & & & $6-15$ years & 127 & 44.7 \\
\hline Below G.C.E(O/L) & 96 & 33.8 & above 15 years & 52 & 18.3 \\
\hline
\end{tabular}




\begin{tabular}{|c|c|c|c|c|c|}
\hline G.C.E(O/L) & 92 & 32.4 & Total & 284 & 100.0 \\
\hline G.C.E(A/L) & 66 & 23.2 & Sources of Fund & & \\
\hline Technical & 19 & 6.7 & Individual saving & 33 & 11.6 \\
\hline Vocational & 5 & 1.8 & family & 94 & 33.1 \\
\hline $\begin{array}{l}\text { University or college } \\
\text { of education }\end{array}$ & 6 & 2.1 & Banks & 82 & 28.9 \\
\hline Total & 284 & 100.0 & NGOs & 31 & 10.9 \\
\hline Marital Status & & & friends / relations & 22 & 7.7 \\
\hline Unmarried & 93 & 32.7 & MFIs & 17 & 6.0 \\
\hline Married & 184 & 64.8 & Others & 5 & 1.8 \\
\hline Widows & 6 & 2.1 & Total & 284 & 100.0 \\
\hline Disable & 1 & .4 & & & \\
\hline Total & 284 & 100.0 & & & \\
\hline
\end{tabular}

Source: Survey results

Personal or demographic profiles of respondents include entrepreneurs by age, education, marital status, size of the organization, working experience and sources of fund.

\subsection{Descriptive Analysis}

Followed by the data presentation, data were analyzed using descriptive statistics. Descriptive analysis was carried out for dimensions of success factors of women entrepreneurs. Descriptive statistics like mean and standard deviation for success factors had been calculated. Descriptive analysis shows that the mean value of all dimensions of determinants of success factors of women entrepreneurs and standard deviations are above $50 \%$.

Cronbach's alpha value was computed to check the reliability of the data. It was compared to the reliability value with the standard value of 0.7 advocated by Cronbach (1951), a more accurate recommendation (Nunnally \& Bernstein's, 1994) or Bagozzi \& Yi's (1988) recommended the standard value of 0.6 as the reliability value. Validation procedures were involved in the initial consultation of the research instrument / questionnaires and the expert's opinion was incorporated. 


\section{1l Macrothink}

Table 3. Reliability statistics

Cronbach's Alpha N of Items

Source: Survey results

\subsection{Factors Measuring the Success Factors}

By doing principal component analysis the communalities of the selected 31 variables have good reliability and intensely checked that no one variable has low loading, ie, less than 0.5 . Thus finally, the 31 variables were selected for factor analysis.

\subsection{KMO and Bartlett's Test}

The appropriateness of the data for the factor analysis was discussed in examining KMO and Bartlett's' test. From this test it was clear that a sample size of two hundred and eighty four as used in the present study was good for a suitable factor solution because all communalities were above 0.6.

Table 4. KMO and Bartlett's Test

Kaiser-Meyer-Olkin Measure of Sampling Adequacy. $\quad 0.820$

\begin{tabular}{|c|c|c|}
\hline \multirow{3}{*}{ Bartlett's Test of Sphericity } & Approx. Chi-Square & $5.539 \mathrm{E} 8$ \\
\hline & df & 465 \\
\hline & Sig. & 0.000 \\
\hline
\end{tabular}

Source: Survey results

Kaizer (1974) recommended that the value of KMO should be greater than 0.5. Field (2000) stated that the values of KMO from 0.5 to 0.7 are moderate, 0.7 to 0.8 are good, and 0.8 to 0.9 are superior. In the present study, the value of $\mathrm{KMO}$ for overall matrix was 0.820 and thereby indicating that the sample taken to process the factor analysis is statistically significant. Further, to define the factors clearly, it was decided to delete any variable that had loading below 0.50. By considering this criterion, a series of factor analysis was performed on the data. After this preliminary step, factor analysis with principal component analysis as an extraction method was performed on these items. 
Table 5. Total variance explained after Extraction

\section{Total Variance Explained}

Component Initial Eigenvalues

Extraction Sums of Squared Rotation Sums of Squared Loadings

Loadings

\begin{tabular}{|c|c|c|c|c|c|c|c|c|c|}
\hline & Total & $\begin{array}{l}\text { \%of } \\
\text { Variance }\end{array}$ & $\begin{array}{l}\text { Cumulative } \\
\%\end{array}$ & Total & $\begin{array}{l}\text { \%of } \\
\text { Variance }\end{array}$ & $\begin{array}{l}\text { Cumulative } \\
\text { e } \%\end{array}$ & e Total & $\begin{array}{l}\text { \%of } \\
\text { Variance }\end{array}$ & $\begin{array}{l}\text { Cumulative } \\
\%\end{array}$ \\
\hline 1 & 8.901 & 28.714 & 28.714 & 8.901 & 28.714 & 28.714 & 5.834 & 18.819 & 18.819 \\
\hline 2 & 2.952 & 9.524 & 38.238 & 2.952 & 9.524 & 38.238 & 3.548 & 11.444 & 30.263 \\
\hline 3 & 2.460 & 7.936 & 46.173 & 2.460 & 7.936 & 46.173 & 3.279 & 10.578 & 40.841 \\
\hline 4 & 1.953 & 6.300 & 52.473 & 1.953 & 6.300 & 52.473 & 2.635 & 8.500 & 49.341 \\
\hline 5 & 1.506 & 4.857 & 57.330 & 1.506 & 4.857 & 57.330 & 2.016 & 6.503 & 55.844 \\
\hline 6 & 1.435 & 4.630 & 61.960 & 1.435 & 4.630 & 61.960 & 1.541 & 4.971 & 60.815 \\
\hline 7 & 1.243 & 4.008 & 65.969 & 1.243 & 4.008 & 65.969 & 1.274 & 4.108 & 64.924 \\
\hline 8 & 1.052 & 3.393 & 69.361 & 1.052 & 3.393 & 69.361 & 1.218 & 3.927 & 68.851 \\
\hline 9 & 1.020 & 3.289 & 72.651 & 1.020 & 3.289 & 72.651 & 1.178 & 3.800 & 72.651 \\
\hline 10 & .908 & 2.929 & 75.580 & & & & & & \\
\hline 11 & .860 & 2.773 & 78.352 & & & & & & \\
\hline 12 & .754 & 2.431 & 80.783 & & & & & & \\
\hline 13 & .704 & 2.271 & 83.054 & & & & & & \\
\hline 14 & .651 & 2.100 & 85.155 & & & & & & \\
\hline 15 & .556 & 1.793 & 86.948 & & & & & & \\
\hline 16 & .501 & 1.615 & 88.563 & & & & & & \\
\hline
\end{tabular}




\begin{tabular}{llll}
\hline 18 & .369 & 1.189 & 91.248 \\
\hline 19 & .348 & 1.121 & 92.370 \\
\hline 20 & .321 & 1.035 & 93.405 \\
\hline 21 & .292 & .942 & 94.347 \\
\hline 23 & .257 & .827 & 95.174 \\
\hline 24 & .241 & .777 & 95.952 \\
\hline 25 & .202 & .653 & 97.319 \\
\hline 26 & .189 & .609 & 97.927 \\
\hline 27 & .148 & .476 & 98.404 \\
\hline 28 & .144 & .466 & 98.869 \\
\hline 29 & .124 & .400 & 99.270 \\
\hline 30 & .121 & .391 & 99.661 \\
\hline 31 & .105 & .339 & 100.000 \\
\hline
\end{tabular}

Extraction Method: Principal Component Analysis.

Source: Survey Results.

Extraction Method: Principal Component Analysis.

From the above table, it could be seen that the Eigen values for the factors 1, 2, 3, 4, 5, 6, 7, 8 and 9 are $8.901,2.952,2.460,1.953,1.506,1.435,1.243,1.052$ and 1.020 respectively. The nine components extracted from the analysis with an Eigen value of greater than one which explained 72.651 percent of the total variance. There is one method to reduce the number of factors to something below that found by using the greater than one rule is to apply the scree plot test. In this test, Eigen values were plotted against the factors arranged in descending order along the $\mathrm{X}$-axis. The number of factors that correspond to the point at which the 


\section{Macrothink}

International Journal of Accounting and Financial Reporting

ISSN 2162-3082 2019, Vol. 9, No. 1

function so produced appears to change slope, was deemed to be the number of useful factors extracted. In this regard the figure of Scree Plot shows the useful factors.

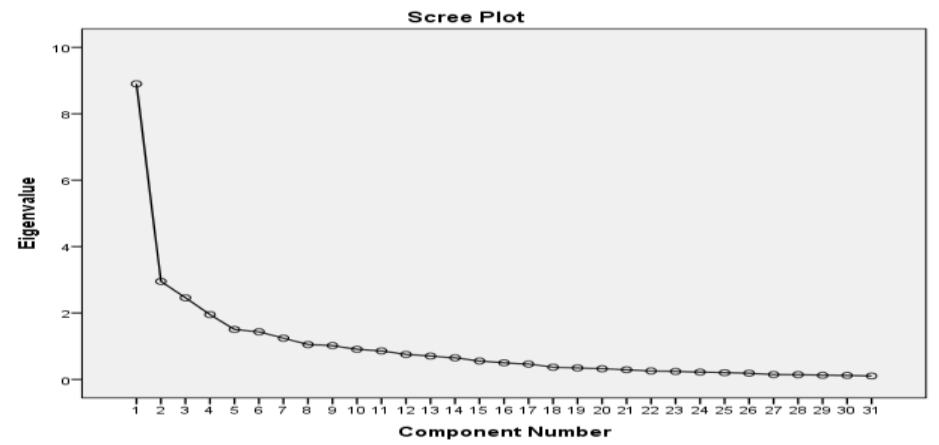

Figure 1. Scree plot

From the figure of Scree Plot it was clear that this data set let to the conclusion that the first nine components should be accepted.

\subsection{Rotated Component Matrix}

The rotated (varimax) loadings for the nine components are presented in the Rotated Component Matrix table.

Table 6. Rotated component matrix for dimensions

\section{Component}

$\begin{array}{lllllllll}1 & 2 & 3 & 4 & 5 & 6 & 7 & 8 & 9\end{array}$

\section{Motivation}

Make my family rich.

Get over shortage of money .788

Attain high social status .749

Be an owner, never an employee.

Acquire lots of wealth for self .660

I am willing to work hard to become the best in my field.

Have my own preferred work style and life style 
I value the courage demonstrated in decisions and actions even in uncertain conditions.

I work with dedication to transform my life into a success story.

\section{Self-efficacy}

Whether or not $\mathrm{i}$ get to be a leader depends mostly on my ability.

I can make good strategic choices. .740

I set up goals for myself and work according to these goals.

For me everything is possible, if I believe I can do it.

\section{Network}

My business contacts and employees refer new .804 customers to my business

My close friends and family provide me with business resources, such as financing or .780 equipment

My close friends and family provide me with practical support for my business, such as ideas, information or advice on how to run my .702 business

My business contacts and employees provide me with practical support for my business such as ideas, information, or advice on how to run .696 my business

My close friends and family provide me with emotional support, such as encouragement, praise or recognition for my business 
My business contacts and employees provide me with emotional support, such as couragement, praise, or recognition for my .550 business.

\section{Risk taking and Tolerance}

I have a strong inclination towards projects with high risk (with high and uncertain rates of .815 return).

It is more fun to tackle a complicated problem than to solve a simple one.

Many our most important decisions are based upon insufficient information.

To great extent my life is controlled by accidental happenings.

\section{Financial strength}

Ensure financial stability of children.

Get best monetary returns for my talents

.705

Enjoy best luxuries of life

.576

\section{Locus of Control}

I feel like what happens in my life is mostly

determined by powerful people.

I prefer to work with difficult partners, but who are very competent.

\section{Problem solving}

There is really no such thing as a problem that can't be solved.

\section{Leadership}

Be a leader.

\section{Environment}


In general, I am of the opinion that, taking into consideration the environment, it is best to examine gradually and with prudence the environment and act accordingly.

Extraction Method: Principal Component Analysis.

Rotation Method: Varimax with Kaiser Normalization.

Source: Field of study

After obtaining the factor clarifications, wherein all the variables have a substantial loading on a factor, the researcher tried to assign meanings to the pattern of factor loadings. The researcher has already examined all the highlighted variables for a particular factor and placed greater importance on those variables with higher loadings to assign a name or a label to a factor. All the 9 factors were given appropriate names on the basis of variables represented in each case.

Each of nine components groups listed in the above table. Factor 1 explains 8.901 percent of the variation and consists of nine variables. The nine variables reflect the successful factors of women entrepreneurs in Northern Province of Sri Lanka. Hence, the researcher names this segment of the successful variable is Economic motivational factor of women entrepreneurs. Factor 2 explains 2.952 percent of the variation and consists of four variables. The four variables reflect the successful factors of women entrepreneurs in Northern Province of Sri Lanka. Hence, the researcher names this segment of the successful variable is self-efficacy of women entrepreneurs. Factor 3 explains 2.460 percent of the variation and consists of six variables. The six variables reflect the successful factors of women entrepreneurs in Northern Province of Sri Lanka. Hence, the researcher names this segment of the successful variable is network affiliations of women entrepreneurs. Factor 4 explains 1.953 percent of the variation and consists of four variables. The four variables reflect the successful factors of women entrepreneurs in Northern Province of Sri Lanka and it was named as risk taking and tolerance of women entrepreneurs. Factor 5 explains 1.506 percent of the variation and consists of three variables which reflected the financial strength of women entrepreneurs. Factor 6 explains 1.435 percent of the variation and consists of two variables reflected locus of control of women entrepreneurs. Factor 7, 8 and 9 explained 1.243, 1.052 and 1.020 percent of the variations and consists of one variable each. These variables reflected successful factors of women entrepreneurs and the researcher named this segment of the successful variables are problem solving, leadership skill and environment of women entrepreneurs. Finally The successful factors of women entrepreneurs in Northern Province of Sri Lanka in the present study composed nine factors namely economic motivation, self-efficacy, network, risk taking and tolerance, financial strength, Locus of control, Problem solving, Leadership and environment .

People who are internally motivated create businesses that survived and attain business success Economic motivation is an important tool to success of the business. Self-efficacy refers to what we believe about our self, rather than how we truly are. Out-of-balance 
self-efficacy affects productivity. A person with low self-efficacy run the risk of performing tasks below her actual ability level because she believes she can only perform to that level. On the other hand, self-efficacy that goes too high may give an individual an unrealistic picture of her capability to do a certain task. Network refers the social networking that refers to friendliness and desire to interweave the relationship with other entrepreneurs which leads to get support at high level and get success. The aspects of risk-taking described the readiness of entrepreneurs to engage in the risky work or no bail. It refers to the ability to cover possible loss turned over decisions carried out in their business. Positive attitude towards risk will allow the entrepreneur success and continuing in its business. Business financial strength is of vital concern to business owners, corporate managers, investors and lenders which leads to business success. A locus of control is a belief about whether the outcomes of our actions are contingent on what we do (internal control) or on events outside our personal control (external control). Problem solving and leadership are important aspects in any businesses to get success of their businesses due to their conceptual thinking and leadership skill. Environment factors are more significant to the women entrepreneurial success. The business environment factors stance challenges to entrepreneurs' success because they are external control of the business.

\subsection{Regression Analysis}

For the regression analysis, the study adopts the use of a single item direct measures of overall success factors were used. The regression model considers the 9 dimensions as the independent variables and the overall success of entrepreneurs as the dependent variable. The adjusted R2 of 19.4 percent of the variance in the overall success of entrepreneurs is predicted. Further, the results also indicated that not only all these nine variables to be the significant predictors of overall success of women entrepreneurs other variables which are not explained here are also the determinant factors of success which were identified from the empirical studies. Further, in these selected factors, except the factors of risk-taking and Problem solving, others have a significant impact on entrepreneurial success because the $\mathrm{P}$ value is less than 0.05 . It is illustrated in the following table.

Table 7. Model test

\begin{tabular}{lllll}
\hline S. No. & Factors & $\begin{array}{l}\text { Standardized } \\
\text { Coefficients (Beta })\end{array}$ & t value & P value \\
\hline & Constant & & 2.206 & .028 \\
\hline 1 & Economic Motivation & .310 & 5.475 & .000 \\
\hline 2 & Self-efficacy & .313 & 5.531 & .000 \\
\hline 3 & Network affiliation & .386 & 7.023 & .000 \\
\hline 4 & Risk taking & .037 & .628 & .531 \\
\hline
\end{tabular}




\begin{tabular}{lllll}
\hline 5 & Financial strength & .241 & 4.175 & .000 \\
\hline 6 & Locus of control & .245 & 4.235 & .000 \\
\hline 7 & Problem solving & -.039 & -.656 & .512 \\
\hline 8 & Leadership & .123 & 2.086 & .038 \\
\hline 9 & Environment & .157 & 2.671 & .008
\end{tabular}

a. Dependent Variable: Ave. success at 0.05 percent level

Table 8. Model summary

\begin{tabular}{llllc}
\hline Model R & R Square & $\begin{array}{l}\text { Adjusted } \\
\text { Square }\end{array}$ & $\begin{array}{c}\text { RStd. Error of } \\
\text { the Estimate }\end{array}$ \\
\hline 1 & $.469^{\mathrm{a}}$ & .220 & .194 & .86382 \\
\hline
\end{tabular}

a. Predictors: (Constant), VAR9, VAR7, VAR8, VAR6, VAR4, , VAR3, VAR5, VAR2

Northern Province is a war-affected area which has been damaged by war situation and people are in a critical condition. This study attempted to identify the factors which are contributing to their way of success. The factor analysis was employed to find out the factors which contributed to the women entrepreneurs' success. Further regression analysis was made to find out the impact of these nine factors on their success. From the regression analysis it was revealed that around $20 \%$ of overall success was predicted by these variables and other $80 \%$ explained by other factors.

\section{Conclusion}

Further, the study revealed except risk taking and problem solving other factors have an significant impact on success of women entrepreneurs in Northern Part of Sri Lanka. Therefore the $\mathrm{H}_{1}$ could be proved that there is relationship between identified factors and success of women entrepreneurs. Further, $\mathrm{H} 2$ also is supported because all factors have a significant impact on success of women entrepreneurs except risk taking and problem solving. These results are consistent with previous studies. Sandip Sarker (2015) identified 8 factors from 25 factors as significant for their success by conducting factor analysis which includes motivation as one of the factors. It is consistent with Thibault et al. (2002) suggested motivation is one of the successful factors. Further, the result consistent with Theo et al., 2007, Enock (2010), Further, Samiti (2006) and Tan (2000), Karimi (2005), Learner and Hisrich (1997), stated that network, financial strength, motivation and environment are the important factors contributing success of women entrepreneurs. Further, by conducting interview and focus group discussions the above results were confirmed by the respondents. They agreed that economic motivation, network affiliations, financial strength, environment, self-efficacy, locus of control and leadership are the influencing factors on their success 
rather than problem solving and risk taking. Further, they emphasized that they lost their properties and loved ones during the 30 year war situation and they were unable to forget the situation and that is the reason not to take risk on ventures and unable to resolve the problems on this regards.

\section{Contribution of the Study}

This study can be input to existing women entrepreneurs and potential entrepreneurs in Northern Province of Sri Lanka to alleviate the problems that women entrepreneurs face. At the same time, researchers and policymakers regarding the field of women entrepreneurship can use these findings to foster the strategic movement of potential and actual women entrepreneurs. Furthermore, considerate the relationship between several success factors will cover the mode for future researchers to study more intricate model. This study may have insinuations for educators, policy makers, trainers and future practitioners whose aim is to study about women entrepreneurs. Another consequence that can be taken into contemplation for future research and factors identified by this study can be used to build a model for women entrepreneur success in the study region. In addition to this, qualitative method can be used for further analysis about influencing factors on success of women entrepreneurs and how much significant those factors and what are the other are for women entrepreneur success.

\section{Limitations}

Some limited factors were considered to identify the success of the activity. The sample size of the study was restricted to 300 women entrepreneurs and the demographic factors of the entrepreneur were not considered for their success. The difficulty encountered in the research was that various kinds of entrepreneurs were grouped together only who have three years' experience on their business.

\section{References}

Abdul, M. A., Omar, N. H., \& Yee, L. K. (2012). Critical success factors of entrepreneurs in business. Journal of Social Sciences and Humanities.

Afrin, S., Isla, N., \& Ahmed, U., S. (2008). A Multivariate Model of Micro Credit and Rural Women Entrepreneurship Development in Bangladesh. International Journal of Business Management, 3(8), 169-185.

Akhalwaya, A., \& Havenga, W. (2012). The Barriers that hinder the success of Women Entrepreneurs in Gauteng, South Africa. International Journal of Sustainable Development, $3(5)$.

Aktaruddin, M. (1999). A case study of Some Successful and Unsuccessful Entrepreneurs in Bangladesh. Journal of Business Administration, 25, 89-126.

Alam, S. S., Jani, M. F. M., \& Omar, N. A. (2011). An empirical study of success factors of women entrepreneurs in southern region in Malaysia. International Journal of Economics and Finance. 
Amarasiri, J. (2002). An exploratory study on a group of selected business women in Sri Lanka. Paper presented at the Eighth National Convention on Women's Studies. Colombo: Centre for Women's Research.

Amit, R., MacCrimmon, K., Zietsma, C., \& Oesch, J. (2000). Does money matter? Wealth attainment as the motive for initiating growth-oriented technology ventures.

Ashraf, M. F., \& Qureshi, T. M. (2010). Risk taking and essential success factors: A comparative analysis in $21^{\text {st }}$ century entrepreneurial dimensions. Mustang Journal of Business \& Ethics.

Bagozzi, P., R., \& Yi, Y. (1988). On the Evaluation of Structural Equation Models. Journal of the Academy of marketing Science, 16(1).

Brown, R. C. (2008, February). Access to finance for women in business: myths or realities. Keynote Address at the International Conference for Women in SMEs, Stellenbosch, South Africa. Bangladesh Women Chamber of Commerce and Industry (BWCCI).

Chandralekha, K., Lavoie, D. Ferhana, K., \& Aparna, I. (1995). Making of rural entrepreneurs - role of support systems. Paper presented at the Internationalizing Entrepreneurship Conference in Bunbury, Australia.

Cooper, A. C., Gimeno-Gascon, F. J., \& Woo, C. Y. (1994). Initial human and financial capital as predictors of new venture performance. J. Bus. Venturing, 9(5), 371-395.

Cronbach, J. J. (1951). Coefficient Alpha and the Internal Structure of Tests. Psychometrics, 6(3), 297-334.

Dafna, K. (2008). Managerial performance and business success: Gender differences in Canadian and Israeli entrepreneurs. Journal of Enterprising Communities: People and Places in the Global Economy, 2(4), 300-331.

Davidson, M. J., \& Burke, R. J. (2011). Women in management worldwide: Progress and prospects (2nd ed.). Surrey: Gower Publishing.

Delmar, F., \& Wiklund, J. (2008). The effect of small business managers' growth and motivation on firm growth: a longitudinal study. Entrepreneurship Theory and Practice.

Department of Census and Statistics. (2004). Annual report of the Sri Lanka labour force survey 2004, with Provincial and District level data. Colombo: Author.

Dharmaratne, K. L. B. G. (2012). Impact of Individual Factors on the Business Performance of Women Entrepreneurs in Sri Lanka. Sabaragamuwa University Journal, 11(1), 139-165.

Enock, N. (2010). What are the factors limiting the success and/or growth of small businesses in Tanzania: An empirical study on small business growth. Master's thesis, University of Arcada. Arcada, Tanzania.

Eshetu, B., \& Zeleke, W. (2008). Women entrepreneurship in micro, small and medium enterprises: The case of Ethiopia. Journal of International Women's Studies, 10(2), 3-5. 


\section{MInstitute ${ }_{\text {Int" }}^{\text {Macrothink }}$}

International Journal of Accounting and Financial Reporting

ISSN 2162-3082 2019, Vol. 9, No. 1

Farook, M. R. M. (1992). Traditional and new entrepreneurs in Sri Lanka. In G. Nanayakkara (Ed.), The Emerging Economic Order in Sri Lanka, Managerial Leadership (pp. 107-117). Colombo: Postgraduate Institute of Management, University of Sri Jayewardenapura.

Fernando, A. K. A. (2006). Entrepreneurship and exploration of barriers to learning and practicing entrepreneurship. Paper presented at the International Conference of Business Management, Nugegoda: University of Sri Jayewardenepura.

Fielden, L. S., Davidson, J. M., Dawe, J. A., \& Makin, J. P. (2003). Factors inhibiting the economic growth of female owned small businesses in North West England. Journal of Small Business and Enterprise Development, 10(2).

Fridah, M. M. (2012). The Challenges Facing Small-Scale Women Entrepreneurs: A Case of Kenya. International Journal of Business Administration, 3(2), 23-45.

Gemechis, T. (2007). Attitude of College Students towards Entrepreneurship: A Case Study of Addis Ababa University and Rift Valley University College. Addis Ababa, Ethiopia. Unpublished Thesis.

Gunatillake, G. (1992). The entrepreneur and the emerging economic order. In G. Nanayakkara (Ed.), The Emerging Economic Order in Sri Lanka, Managerial Leadership (pp. 31-44). Colombo: Postgraduate Institute of Management, University of Sri Jayewardenapura.

Gundry, L. K., Ben-Yoseph, M., \& Posig, M. (2002). Contemporary Perspectives on Women's Entrepreneurship: A Review and Strategic Recommendations. Journal of Enterprising Culture, 10(1), 67-86.

Hamilton, D. (1993). Ecological basis for the analysis of gender differences in the predisposition of self-employment. In H. Klandt (Ed.), Entrepreneurship and Business Development. Avebary, Aldershot.

Helms, M. (1997). Women and Entrepreneurship: The Appealing Alternative. Business Perspectives, 10(1), 16-19.

Hisrich, R. D. (2005). Entrepreneurship: New Venture creation (5th ed.). Tata Mc Graw Hossienie.

Karimi, Z. (2005). The role of government support in expanding entrepreneurship among women: Case Study: women's cooperatives in Mazandaran province, the first conference women entrepreneurs and the challenges facing it. Association of Women Entrepreneurs' manager.

Karunanayake, G. P., \& Senadheera, G. D. V. R. (2006). Strategic orientation of entrepreneurs in small and medium enterprises. Paper presented at the International Conference of Business Management, Nugegoda: University of Sri Jayewardenepura.

Kodithuwakku, A. (1992). The entrepreneur in the changing economy of Sri Lanka. In G. Nanayakkara (Ed.), The Emerging Economic Order in Sri Lanka, Managerial Leadership (pp. 


\section{MInstitute Macrothink $^{\text {Int }}$}

International Journal of Accounting and Financial Reporting ISSN 2162-3082

118-128). Colombo: Postgraduate Institute of Management, University of Sri Jayewardenepura.

Kodithuwakku, S., \& Perera, S. (2003). Women entrepreneurship development in Sri Lanka: Aiming for business success, pp. 43-44. Colombo: International Labor Organization.

Koh, H. C. (1996). Testing hypotheses of entrepreneurial characteristics: A study of Hong Kong MBA students Journal.

Learner, M., Brush, C., \& Hisrich, R. (1997). Israel Women Entrepreneur: An Examination of factors affecting Performance. Journal of Business, 122-129.

Mahbub, U. H. (2000). Human Development Centre, Human Development in South Asia: The Gender Question. Oxford University Press.

Marlin, L. M., \& Wright, L. T. (2005). No Gender in Cyberspace?. International Journal of Entrepreneurial Behaviour and Research, 11, 162-178.

McKay, S. (2001). Women Entrepreneurs: Moving beyond family and Flexibility. International Journal of Entrepreneurial Behavior \& Research, 7, 148-165.

Naser, K. K., Mohammed, R. W., \& Nuseibeh, R. (2009). Factors that affect women entrepreneurs: evidence from an emerging economy. International Journal of Organizational Analysis, 17(3), 225-247.

Nunnally, J. C., \& Bernstein, I. H. (1994). The Assessment of Reliability. Psychometric Theory, 3, 248-292.

Perera, T., \& Buddhadhadasa, S. (1992). Characteristics of Sri Lankan entrepreneurs: How valid is the Schumpeterian model?. In G. Nanayakkara (Ed.), The Emerging Economic Order in Sri Lanka, Managerial Leadership (pp. 83-92). Colombo: Postgraduate Institute of Management, University of Sri Jayewardenepura.

Perren, L. (1999). Factors in the growth of micro-enterprise: Developing a framework. Journal of Small Business and Enterprise Development.

Rahman, \& Hossain. (1999). Micro Credit Initiatives for equitable and sustainable development.

Rahman, H. A. H. M., Mian, M. A., Bhattacharjee, D., \& Khan, A. R. (1979). Entrepreneurship and Small Enterprise Development in Bangladesh. Dhaka: University of Dhaka, Bureau of Business Research.

Ranasinghe, S. (1996). Entrepreneurship education and training in Sri Lanka. Sri Lanka Journal of Management, 1(3), 262 - 277.

Saleh, A. (1995). A Profile of the Women Entrepreneurship in Bangladesh. Journal of Business Studies, 16(1), 159-170.

Samiti, V. (2006). A research study on entrepreneurial challenges for SC Persons. 


\section{Ml Macrothink}

International Journal of Accounting and Financial Reporting

ISSN 2162-3082 2019, Vol. 9, No. 1

Sandberg, K. W. (2003). An exploratory study of women in micro enterprises: Gender related differences. Journal of Small Business and Enterprise Development, 10(4), 408-417.

Sarkar, S., \& Palit, M. (2014). Determinants of Success Factors of Women Entrepreneurs in Bangladesh - A Study Based on Khulna Region. Business and Economic Research, 4(2).

Schlosser, G. A. (2001). Stories of success from eminent Finnish women: A narrative study. High Ability Studies, 12(1), 61-88.

Seuwandhi, B., \& Ranasinghe. S. (2008). Factors contributing to the successs of women entrepreneurs in Sri Lanka. Sri Lanka Journal of Advanced Social Studies, 1(2).

Stoner, C. R., \& Hartman, R. I. (1990). Work-Home Role Conflict in Female Owners of Small Businesses: An Exploratory Study. Journal of Small Business Management, 28(1).

Theo, W. M., \& Chong, S. (2007). Theorizing a framework of Factors Influencing performance of Women Entrepreneurs in Malaysia. Journal of Asia Entrepreneurship and Sustainability, 3(2), 1-17.

Thibault, M., Wilcock, A., \& Kanetkar, V. (2002). An exploratory study of factors influencing sales performance of small and medium - sized enterprises. Proceedings of the Administrative Sciences association of Canada. Winnipeg, Manitoba.

Vob, R., \& Muller, C. (2009). How are the conditions for high-tech start-ups in Germany. International Journal of Entrepreneurship and Small Business, 7(3), 285-311.

Wendy, T., \& Still, V. L. (2000). Women's Business: The Flexible Alternative Work Style for Women. Women in Management Review, 15(5/6).

White, B., \& Cooper, C. L. (1997). A portrait of successful women. Women in Management Review, 12(1), 27-34.

Winn, J. (2005, September). Women Entrepreneurs: Can We Remove the Barriers?. The International Entrepreneurship and Management Journal, 1(3), 381-397.

World Bank. (2003). Importance of SMEs and the Role of Public Support in Promoting.

\section{Copyright Disclaimer}

Copyright for this article is retained by the author(s), with first publication rights granted to the journal.

This is an open-access article distributed under the terms and conditions of the Creative Commons Attribution license (http://creativecommons.org/licenses/by/4.0/) 